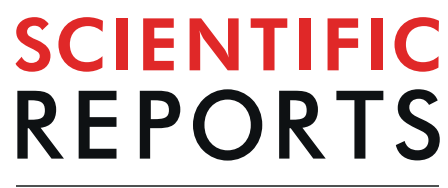

natureresearch

Check for updates

\title{
OPEN Author Correction: Comparative analysis of HER 2 copy number between plasma and tissue samples in gastric cancer using droplet digital PCR
}

\section{Boram Kim (D), Soo Kyung Nam, Soo Hyun Seo, Kyoung Un Park, Sang-Hoon Ahn, Do Joong Park, Hyung-Ho Kim, Woo Ho Kim (i) \& Hye Seung Lee (iD)}

Correction to: Scientific Reports https://doi.org/10.1038/s41598-020-60897-4, published online 06 March 2020

In the HTML and PDF of the original version of this Article Hye Seung Lee was incorrectly affiliated with "Department of Laboratory Medicine, Seoul National University Hospital, Seoul, 03080, Republic of Korea" The correct affiliations for Hye Seung Lee are listed below.

Department of Pathology, Seoul National University Bundang Hospital, Seongnam, 13620, Republic of Korea.

Department of Pathology, Seoul National University College of Medicine, Seoul, 03080, Republic of Korea.

Additionally, the Supplementary Figure S1 file contained errors in the affiliation list where affiliations 2, 4 and 6 were omitted. As a result, affiliation 3 was listed as affiliation 2, affiliation 5 was listed as affiliation 3 and affiliation 7 was listed as affiliation 4 .

These errors have now been corrected in the PDF and HTML versions of the Article, and in the accompanying Supplementary Information file.

\begin{abstract}
(c) (i) Open Access This article is licensed under a Creative Commons Attribution 4.0 International License, which permits use, sharing, adaptation, distribution and reproduction in any medium or format, as long as you give appropriate credit to the original author(s) and the source, provide a link to the Creative Commons license, and indicate if changes were made. The images or other third party material in this article are included in the article's Creative Commons license, unless indicated otherwise in a credit line to the material. If material is not included in the article's Creative Commons license and your intended use is not permitted by statutory regulation or exceeds the permitted use, you will need to obtain permission directly from the copyright holder. To view a copy of this license, visit http://creativecommons.org/licenses/by/4.0/.
\end{abstract}

(C) The Author(s) 2020 